\title{
Top Boy: Cultural Verisimilitude and the Allure of Black Criminality on UK Public Service Broadcasting Drama
}

\begin{abstract}
In the early 2000s, a new form of multicultural television drama began to emerge in the UK, exploring contemporary gang life within Britain's black communities. A notable example of this 'black urban crime' genre is Top Boy, screened by the UK's leading multicultural public service broadcaster, Channel 4, between 2011 and 2013. This article produces an analysis, drawing on sociological and media studies perspectives, and through historicization and contextualisation, that seeks to understand the fascination of the black urban crime genre for programme-makers, broadcasters and audiences in the contemporary British mediascape. It locates Top Boy at the intersection of complex media relations and modes of production that are themselves intertwined with political, legislative and cultural agendas tied to postmulticulturalist and neoliberalist tendencies within public service broadcasting frameworks. The article suggests that black urban crime narratives do not advance understandings of the organizational structure of urban gangs or drug related crime that are so central to these texts; nor do they offer a progressive contribution to contemporary debates or representation of black criminality.
\end{abstract}

Keywords: Black, Crime, Drama, Television, Multiculturalism, United Kingdom, Channel 4, Urban, Public Service Broadcasting 


\section{Introduction}

The rise of the urban, multicultural television drama in the 2000s represents a critical shift in the media's representations of black communities. The trend is exemplified by a recent surge of texts preoccupied with the notion of a black 'underclass', locked in by criminality, social disadvantage and a localised drugs trade; notably situated within a social realist framework. This article offers a critical examination of the rise of the black urban crime narrative in the context of public service broadcasting (PSB) in the United Kingdom (UK) and analyses the manifold motivations for its production in contemporary cultural and political contexts. The article considers the political milieu within which the genre has emerged and suggests that the former UK Government's conceptualisation of both multiculturalism and 'urban' criminality within its New Labour neoliberal agenda in the 1990s and early 2000s influenced the particular nuance inscribed in this latest 'authentic' cultural representation of black criminality. We will draw on the example of the critically-acclaimed social realist series, Top Boy, screened on Channel 4 in 2011-13. For researchers within and beyond television studies, Top Boy presents a powerful example of how traditional mainstream media (including media that is framed through the lens of public service) continues to produce and reaffirm normative cultural meanings around 'race' and criminality in contemporary contexts.

We propose that the mainstream media and state agents play a key role in instituting representations of black criminality and specifically, the contemporary 'black gang, gun and knife crime' consensus. Alongside an analysis of its textual features, a fundamental aspect of this discussion is Top Boy's production context; the circumstances in which 'black urban crime drama' is itself conceptualised and produced within a television apparatus that is 
subject to and constituted by market and cultural influences that, in turn, help to shape the text's final form and meaning. This also involves acknowledging the legislative changes in the 1990s that led to an abatement of ethnic minority production within UK PSB, specifically with regard to ideas of (post) multiculturalism and how Channel 4 responded to this. The effects of these various influences are discussed in relation to a rearticulated multicultural social realist dramatic form that is centered on notions of the urban linked to the social constructions of 'blackness', crime and masculinity. We are interested in the cultural dynamics that produce the racialized meanings associated with certain kinds of crime in these salient, current contexts.

Our analysis is divided into three interwoven sections with overlapping concerns that are addressed through historicization and contextualization. Firstly, we explore the wider agenda of the neoliberal politics/Channel 4 embrace. Second, we consider media culture and notions of cultural verisimilitude and the ways in which the black urban crime narrative articulates notions of depolitisiation and utilitisation of BAME (Black and Minority Ethnic) in media culture. And third, through an analysis of Top Boy, we consider the generic maneuvers of social realism as a tool through which to represent black criminality to wider publics.

\section{Channel 4, New Labour, and the Allure of the Black Urban Crime Narrative}

UK Television's relationship with its ethnic minority population came to fruition with the advent of Channel 4 in 1982, with programming devised specifically for black and ethnic minority audiences emerging as a direct result of the Annan Report's recommendations for the 'fourth channel' to cater for the interests of minority audiences as part of a wider commitment to PSB. The 1981 Broadcasting Act gave the Independent Broadcasting 
Authority (IBA) responsibility for establishing Channel 4 and decreed several programming obligations the channel would need to fulfill in order to demonstrate its PSB remit. Most notably, they were required to 'ensure that the programmes contain a suitable proportion of matter calculated to appeal to tastes and interests not generally catered for by ITV' (Broadcasting Act, 1981). This was of particular importance in the 1980s, considering existing racial tensions within British society, with Lord Scarman's report into the 1981 Brixton Riots the genesis for a 'comprehensive, grounded political programme of accommodating cultural minority needs' (Vinen, 2010: 90).

These macro developments emerged in linearity with theories from Sociology and Cultural Studies scholars such as Hall et al (1979) Hall (1981) Gilroy (1987) and Solomos (1988) who advanced arguments that media representations of black youths were not only complicit in demonising them but that such approaches had significantly impacted the discriminatory experiences of black men within the British judicial system, an experience in which black youths become the 'other' in media discourse. Early attempts to formulate a sociological understanding of media representations of black British youths generally took a critical approach to the practices of institutional power, and Hall's Policing the Crisis stands out as the seminal text providing an analysis of the British state, authoritarian populism and the turn to market solutions. His work is important for highlighting how the specific cultural contexts (television, film and print media) in which the construction of such hegemony takes place are often heavily racialized through the use of racial stereotyping, and in order to create consensus. Specifically, Hall (1981) problematized the race discourses articulated by and through a white-centric media and a principle tenet of the otherness that emerges from such a framework. 
The socio-political climate of the early 1980s supported the implementation of certain government initiatives that led to establishment of Channel 4. The challenge to hegemonic narratives of race and blackness was most dramatically expressed in films of the black film and video independent workshop collectives that emerged in the mid-1980s such as the Black Audio Film Collective, Ceddo and Sankofa, with the sustained support of Channel 4 proving favourable for filmmakers wishing to use screen media to produce visual counter narratives to political hegemony (Mercer 1987). Many of these films were given a terrestrial platform on the newly established Channel 4 and investigated the discrimination, social exclusion and stigmas that defined everyday modes of existence for Britain's black communities at the time, with a form and content antithetical to British television's previous role as a largely consensus-producing vehicle for racial stereotyping. Notably, documentaries such as The Peoples Account (Ceddo, 1985), which investigated the Broadwater Farm riots from the perspective of the communities involved, revealed 'the antagonistic relationship between the police and the residents and how the media colluded with the police in distorting the real causes of the uprising' (Friedman, 1993: 131). Such texts were defined by Kobena Mercer (1994) as dialogical, in that they offered a counter hegemonic response to racist stereotypes, engaging with the lived politics of racism and representation that produced a "critical dialogue' (239). Many of the issues addressed by early Channel 4 with regards to black television production - the ontology of multiculturalism, the question of television as social practice and issues of narrative choice and authorship - fed into ideas being explored by scholars and cultural theorists of the time; questions of televisual representation and its sociocultural significance as a form of expression (Fiske, 1987, Williams, 1977). 
The new neoliberal model of PSB that began its ascendancy at Channel 4 after the 1990 Broadcasting Act and has deepened over the past two decades comprised of an array of changes at the level of commissioning, production, and content. For Channel 4, these changes included a shift from a radical television culture as an outlet for minority viewpoints toward the commissioning of programming targeted at the (assumed) tastes and interests of mainstream British culture and audiences. UK academics have explored the introduction and representational consequences of this remit shift within the context of PSB (Brown, 2007, Friedman, 1993, Hobson, 2007). The sociopolitical influences that imbued a redefinition of multicultural representation and the abatement of black content providers was the consequence of an increasingly competitive marketplace that undermined many of the values of Channel 4's original remit (Malik, 2013). This was also part of a broader turn, developing since the turn of the millennium, in which serious challenges to multiculturalism policies and institutional frameworks were being posed (Vertovec, 2010). For PSB, this meant a discursive orientation away from discrimination, inequality and social justice concerns (apparent in early Channel 4) and towards a broad conception of 'individuality' coupled with the arguments of the market state, licensed by this new politics of post-multiculturalism (Malik, 2013). Simultaneously, an emphasis on modernisation and change lay at the heart of the new selfidentity advanced by the UK's Labour Government (espousing a New Labour ideology under the leadership of Tony Blair) in the late 1990s. The scope of this modernisation included a widely a pervasive discourse of inclusivity, particularly aimed at young black people in the aftermath of the 1999 Macpherson Report which followed the racially-motivated murder of the black British teenager, Stephen Lawrence, in South London in 1993. 
Meanwhile, the advent of urban subculture coincided with the popularising of other black cultural products, such as UK Garage and Grime music, the commercialisation of 'urban clothing' and the prevalence of young black people in mainstream media. Such a commodification of black subculture served the social inclusion agenda well and was aimed at an emerging black British generation distanced from the racial politics of the 1980s and early 1990s. It marked a new modality of multicultural discourse predicated on an enthusiasm for cultural difference or 'cultural diversity'. Thus, 'urban' initially acted as a commercial pseudonym that offered the visage of inclusivity through the 'positive' mainstreaming of black youth subculture by the early 2000s. Coinciding with these various developments was an additional, social policy consequence that, paradoxically, served useful for the twin agendas of both New Labour and Channel 4 in fulfilling a market agenda whilst simultaneously executing their public-facing responsibilities. This involved a new connotation of 'urban'. A spate of knife and gun crimes amongst sections of black working class youths in areas across London in the early 2000s revived issues of black alienation in the public consciousness. 'Black on black' and 'postcode shootings' became interchangeable terms used frequently in popular discourse to describe territorial conflicts between young people from particular districts of London, contributing to a language in the mass media constructed to develop a self-serving prophecy of black crime. For example, in a piece in the Observer titled 'Without a gun, You're Dead' Tony Thompson offered a sensationalised account of the influence of 'original Yardies' who are 'being challenged by gangs of British-born black people who have proved themselves to be capable of just as much violence' (Thompson, 2003). 
The journalistic appetite for the term 'gangs' and the euphemisms associated with gangs (young black men) and 'urban', went on to elicit both interest and fear amongst British publics towards certain cultural 'others'. The 'gangland Britain thesis' (Hallsworth and Young, 2008, 182), based around an apparent rise in 'urban street-based' gangs, has been contested within cultural criminology. The idea of a gang epidemic has been critiqued on the grounds that it reflects tendencies within the media to sensationalise, rather than providing evidence of empirical realities about criminal activity. In addition, within the academic literature, there is a strong emphasis on the ideological basis of 'gang problem' discourse because it locates certain, heavily racialised, communities as a 'suitable enemy' (Christie, 2001).

Sensationalist headlines such as 'Gun crime spreads 'like a cancer' across Britain' (Observer, 5 October 2003), 'The ethnic connection' (Observer, 25 May 2003) 'They'll shoot anyone - even the police' (Guardian, 25 May 2003) and 'Homegrown gangs shoot to power on our violent streets' (Observer, 26 August 2001) combined to advance a culture of anxiety towards young, black working class men in Britain. Within these official discourses, we can identify a tendency to define urban crime as gang related; a process by which black criminals become 'Yardie gangs'. As suggested by Van Duyne (2003), both the media and police regularly express concern over aspects of criminality that are yet to be addressed significantly by academic research, and that are but routinely narrated as organized crime. This context gave an added impetus to the alluring rise of the black urban crime narrative, despite the actually relatively fluid organizational structure of such criminal activity (Stelfox, 2006). Ethnicized accounts became the basis for a concerted effort by print media to establish the 
black gangs discourse and further catalyzed media interest in black, urban youth criminality. This mode of racialised discourse also neglected analytical readings of crime as an outcome of problematic socio-economic structures or institutional power (Metcalf, 2012). Since these crimes appeared to be concentrated within inner city estates, and committed by black people against black people, mainstream media culture combined to pathologise gun crime as emanating solely from within Britain's black community; urban violence was intra-race and thus a problem created by and within black society.

The work of Jewkes (2004) and Best (1995) has analysed the influence of media moral sensationalism on public discourse and opinion, underlining the potential dangers of such coverage in reaffirming cultural stereotypes and stigmas. Within the media, 'urban' became 'a powerful and recognizable 'brand' to 'be pinned to alleged ethnic crime' (Hobbs, 2006: 428). This new 'negative' inflection of 'urban' (and its various hyphens) reinforced notions of a black underclass laying their own lives to waste; a decontextualized interpretation that strengthened hegemonic narratives of black criminality as a cultural consequence. As argued by McKenzie (2015), such culturalist discourses suggest that 'it is their self-destructive behaviour, through their own practices, tastes, what they wear, how they speak and who they decide to share their beds with that begins to represent a real threat to British values and national life' (198). Notions of cultural difference were central to how both the police and mainstream media began to define gang culture and gun and urban crime in general.

A social consequence of such practices was the way in which black communities were deemed to require a particular form of policing. As such, and as has been discussed in other research around the link between black criminal typification and effects on policy (Welch, 2007), the black urban crime narrative provided a rationale for policy directions and practical 
implementation, including initiatives such as racial profiling. Following the 1999 Lawrence Inquiry, the Metropolitan Police established Operation Trident in 2000 with the sole aim of investigating crime within London's black communities. This racialising of crime represented the further neoliberalising of British social life; it seemed to suggest that the police regarded 'black on black' violence as a separate and specific mode of criminality. Thus, in the case of Operation Trident, we see that the state apparatus's response to urban criminality takes on the form of an ideological mode of policing, with mainstream media and state agents playing a key role in instituting the 'black gang, gun and knife crime' consensus.

\section{Cultural Verisimilitude, Screen Media and the Black Crime Discourse}

Film and televisual representations form a key role in helping to producing this discursive culture, with media repetition of black gang crime anecdotes producing a particular modality of racialized moral hysteria. The proliferation of the urban crime narrative prompted a number of British filmmakers, inspired by the media discourses of the time, to engage with themes of black crime in their productions, and gave rise to a new contemporary subgenre in British film and television, the black (youth-orientated) urban crime drama. Two interrelated theories of genre - generic and cultural verisimilitude - are important when we start to explore how this genre reproduces dominant discourses of black criminality. For Steve Neale (2000), in his development of the concept of verisimilitude in theorising the narrative forms of cinema, film genres not only consist of expectations of the text, but also expectations of audiences. Such expectations (character, narrative, location) are cultivated through regimes of verisimilitude. Neale dichotomizes verisimilitude into two (sometimes hybridised) approaches: while generic verisimilitude refers to established conventions of a genre that the text must adhere to, cultural 
(or social) verisimilitude pertains to the dominant ideological discourse, in that it adheres to what is believed to be a true reflection of its subject matter. Crucially, as Tzvetan Todorov (1981) asserts, this does not suggest that cultural verisimilitude represents a fidelity to socio/cultural/political truths, but that it corresponds to popular expectations and discourses purporting to be true.

We can specifically locate both the generic and cultural regimes of verisimilitude that helped produce the black urban crime drama on screen. The highly-acclaimed BBC drama Storm Damage (Simon Cellan Jones, 2000) marked an early demonstration of mainstream broadcasters tapping into gangsterism amongst Britain's BAME youths. The BBC Films/UKFC production Bullet Boy (Saul Dibb, 2005) was released at the apex of the intensive media focus on gun crime and possesses narrative themes that may previously have been defined as anti-national, national cinema (Wayne, 2002). Described by the Observer's Philip French (2005) as a film that 'takes an unflinching look at the choices faced by young black men in today's Britain', the production appeared to possess all the hallmarks of a film which, according to Wayne, 'display an acute attunement to the specific social, political and cultural dynamics within the territory of the nation' (45). Given the dearth of black British film production and the UKFC's rhetoric of cultural diversity (the new mode of addressing ethnic diversity in a post-multiculturalist landscape), Bullet boy was a critical triumph within liberal quarters and hailed as a milestone in realistic portrayals of Britain inner city underclass. A number of films that purported to deal with issues of black crime and gang subculture in London followed, presented through various themes such as the underground music scene in Life and Lyrics (Richard Laxton, 2006), youth delinquency in Kidulthood (Menhaj Huda, 2005) the drugs trade in Rollin' With the Nines (Julien Gibley, 2008) 1 Day 
(Penny Woolcock, 2009) and Shank (Mo Ali, 2010). This trend was also being replicated in television, with Kudos Film \& Television developing West 10 LDN (2008) and Dubplate Drama (2005-2009). While sharing some of the thematic concerns with Bullet Boy, the most successful of these films was Adulthood (Noel Clark, 2008) which acted as a prototype for this production trend, with its contemporary urban milieu and its thematic and narrative conventions demonstrating the genre's considerable commercial potential.

What was clear was that the urban crime narrative had accumulated a deep resonance in the public consciousness and was now a preferred genre for financial investment within the publicly funded cultural sector, often framed through media institutions' strategic purposes around cultural diversity; Adulthood, for example, was one of the top twenty British films of 2008 (UK Film Council 2009). The sociological interest in this topic for producers and filmmakers partly reflected the liberal phenomenon of urban subculture, since it indicated a new form of social identity. Both Bullet Boy and Adulthood had the potential to provide an urgent visual encounter with the lived realities of urban crime, offering a counter-hegemonic account of gun crime in the context of wider socio-economic considerations. However, their decontextualized accounts reflected a broader media discourse by rejecting the idea that urban crime is an outcome constructed by socio-economic inequality and racial discrimination. Instead, the focus was on how urban youths actively marginalised themselves from wider society, an anti-social underclass deliberately pursuing a subculture of criminality. This, of course, also chimed with the New Labour claim that knife and gun murders in London were no outcome of a defective socio-economic structure, but of a distinctive incubus within black culture. For Tony Blair, the (New) Labour Prime Minister: 
Economic inequality is a factor and we should deal with that, but I don't think it's the thing that is producing the most violent expression of this social alienation...I think that is to do with the fact that particular youngsters are being brought up in a setting that has no rules, no discipline, no proper framework around them (Blair in Wintour, 2007)

This rhetoric barely conceals the anxiety at the heart of the black youth crime discourse and Blair's assessment of social alienation as a cultural outcome as opposed to a socio-political process emerged consistent with both broad public opinion and media depictions. In this context, the media reactions to urban crime were framed, we want to suggest, not by social inequality concerns but rather by concepts of how the black underclass had created immoral communities. The various expectations, modalities and indexes of urban crime dramas are particularly germane in the case of Channel 4's Top Boy because of the explicitly social realist framework through which it operated.

\section{Top Boy and the Manoeuvres of Social Realism}

At the peak of gang-related crime in the 2000s media interest in representations of 'black crime' was perceived as inevitable and mimetic. Indeed, the cultural concern within this discussion is not to dispute the validity of mainstream media depictions of criminality amongst young black men. Rather, it is with how mainstream media discourses, framings and constructions of 'race' often work in relation to politically expedient circumstances. Moreover, it is with the specific allure of television drama as a method of social engagement in relation to ideas of 'black urban crime'. For Ellis (1999), television 'acts as our forum for interpretations of the world' (69). Therefore, television drama possesses certain 
epistemological properties and, within a PBS paradigm, provides a common frame of reference for the construction of identities. Bignell et al. (2000) suggests, 'at its best, television drama has provided not only a window to the world but also a critical interrogation of it' (1). This is important because, when situating television drama within didactic contexts, socio-political epistemologies can emerge to counter hegemonic narratives held within the national sphere.

This only partially describes the issue, since practitioners are also influenced by, and operate within wider media structures and political discourses. With regards to the black urban crime narrative, we can start to map the credentials of the genre in the 2000s that also relates to notions of dramatic license and realism. The term 'urban', for example, possesses an articulation beyond ethnicity and social position; and this is the idea of crossover. Whilst the term 'Black' had 'functioned as a political category to unify people of colour in the face of white racism' (Wayne, 2002: 122), with the subtracting of political enquiry, (post) multiculturalist television in this guise could be assimilated, categorized, instrumentalized and commercialised. Thus in terms of audience crossover, the black British urban drama genre functioned, in part, as a welcome departure from the polarized production culture of the 1980s, which had interrogated the social, political and economic marginalities of black Britain (for example, on early Channel 4). The new modality of black drama can therefore be understood not just in relation to a later, post-multiculturalist Channel 4, but also in relation to questions of class, audience and market-share; providing a narrative solution congruent to the way in which middle classes, vis-à-vis the liberal broadsheet press, were able to imagine and pathologize black urban youths in relation to narratives of crime. 
Channel 4's Top Boy exemplifies much of what is being described, because it dramatizes the hegemonic cultural idiolects which mainstream media advocates as being intrinsic to black working class life. This form of representation can be considered in relation to a desire for a new kind of multicultural drama in pulling together many of the issues central to popular discourses in urban culture; deprived social housing, the temptations of violence, gangs and drugs, single-parent families, neglected/misguided children and misplaced loyalties. The catalyst for the development of Top Boy came about after Ronan Bennett, the series creator and screenwriter, observed a twelve year-old orchestrating a drugs transaction in a supermarket car park in Hackney, East London (Bennett, 2011). The idea was later developed with Charles Steel and Alasdair Flind of Cowboy Films, under the supervision of Channel 4 producers Camilla Campbell and Robert Wulff-Cochrane. In a one-off open call, the casting team specifically sought BAME individuals between the ages of thirteen and sixteen, with previous acing experience not required. This form of 'street casting' was married with workshop techniques with a young ensemble cast; a vital strategy for achieving cultural impact amongst young BAME viewers by rendering 'credible' their lifestyles, behavioral characteristics and vernacular and in order to produce a representation of 'authenticity' on screen. As observed by Nosheen Iqbal in the Guardian:

Much was made of Top Boy's tower-block authenticity, but timing, too, had its part to play; the first series arrived, serendipitously, soon after the 2011 London riots, and gave an honest account of inner-city life for young people with no jobs, no prospects and no power beyond their own postcode. It was neither patronising or try-hard - the usual twin criticisms of self-defining gritty urban dramas - and it cast kids from the estates over professional actors, which helped to give the show its bleak realism. (Iqbal, 2013) 
This commentary goes beyond the cultural verisimilitude we have been discussing. Here, interplay is established between the intentions of the critic, the text in question and beliefs held by its readership. Iqbal attempts to locate Top Boy on a sociological terrain by summarising the content, hegemonic assumptions and narrative themes specific to the drama as part of a broader gambit of stimulating audience expectation through a system of generic images, subjecting Top Boy to an array of labels, terms and euphemisms to establish a 'generic corpus' (Neale, 2000) that simultaneously define urban drama as a spectacle. Yet, such generic language has the potency to reinforce, rather than ameliorate black youth crimerelated stigma. By casting a correlation between the 2011 London riots and Top Boy's social realism, terms such as 'inner city life' reinforce dominant characterisations about the nature of 'blackness' and indeed, its pervasive associations with 'gang culture'. As Newburn's Reading the Riots Guardian/LSE report about the causes and consequences of the 2011 London Riots suggests, the role of gangs in the riots was, in fact, minimal (The Guardian, 2011). It is evident then that Iqbal legitimises, through her emphasis on Top Boy's 'honest account', the hegemonic assumptions about both the cause and participants of urban criminality. According to the liberal press, the non-professional cast was perfectly suited to the roles; they not only reproduced the generic images held in public consciousness and were able to provide an authentic vernacular, but the actor's real-life backstory (Ashley Walters, the lead actor, had served a prison sentence for possession of a firearm) re-emphasizes the generic verisimilitude of the drama.

The journalistic reviews promise authenticity and realism, and the representational strategy employed by Top Boy is related to critical questions of realism and generic/cultural 
verisimilitude. However, in order for the drama to be categorised as realist, there must be certain generically verisimilar textual features present. The production relied on filmmakers shooting on location with non-professional actors to emphasize the authenticity of Hackney's social milieu. However, culturally verisimilitudinous elements cannot be achieved without audience awareness and prior knowledge. Therefore, the correspondence between the authenticity of the drama and public expectations are reinforced, as evidenced by Channel 4's press release. Here, sensationalist description provides a fundamental element in establishing the drama's narrative image, and 'an honest and gripping rendition of inner-city drug and gang culture' (Channel 4, 2011) ballasts Top Boy in the generic imagery conducive to its narrative intentions. This marketing approach allowed the drama to establish the generic corpus in a manner designed to attract its intended audience. To enhance the verisimilitude of the text, Bennett, who had lived in Hackney for more than twenty-five years, employed an ethnographic development technique for Top Boy, immersing himself for two years in the local drugs trade and maximizing the use of testimony from drugs dealers, school children, social workers and local residents in order to insert a particular authenticity to its narrative concerns and dialogue. In explaining the dissemination of these interviews into dramatic storytelling, Bennett says:

I do what dramatists do - throw it all into the mix, stir it around and wait to see what characters and storylines emerge. There's not room for everything, and certain of my own preoccupations will always come to the fore: the struggles of disadvantaged kids; the absent father; the man who helps without being pious (Bennett, 2011). 
Here, the recurrent discourse on factuality and generic verisimilitude in relation to a purported realist black drama imbues a voyeuristic anticipation, feeding into what Jauss (1982) has termed the 'horizon of expectation' (79), a unity between the drama's content and an audience already familiar with both its generic corpus and the associated media discourses. Again here, authenticity is guaranteed by the anthropological work of the practitioner. The feature reports on the extent of ethnography required for the drama's development; a classic 'research agenda' is advanced not only to ensure its cultural verisimilitude but to also respond to perpetual questions of fidelity of representation that arise, particularly in PSB contexts of ethnic minority representation. Ahead of its filming, the production drew criticism as a result of its sensationalized narrative; with the shooting location moving to Brixton when filming permission was refused by Hackney Council for the first series in 2011, with Hackney's Mayor stating that:

...it was not fair on residents to run the risk of having their neighborhood stigmatised on national television as riddled with drugs and gangs... what possible justification could the Council give for being complicit in such negative stereotyping? (Quoted in Hackney Citizen, 23 September, 2011).

Although such controversy over the drama created temporary logistical problems for its production, it generated a specific public/media interest and expectations about the drama. In his analysis of film industry promotional practices, Ellis (1981) identifies the construction of a 'narrative image' that emerges from a combination of film-industry publicity material content and the discourses of mainstream media that have become internalised into the fabric of public hegemony. Both cultural and generic verisimilitude performs a defining role in 
producing the realist expectations evident in the publicity for the drama. We can look, for example, at the visual aesthetic of Top Boy's promotional poster. Against the backdrop of twin large high-rise tower blocks, the three principle characters stand (in a parody of an Olympic podium) on a damaged BMW, a dustbin, and a low-rise brick wall surrounded by rubbish bins. The hierarchy established by the varying positions of its characters visually forecasts an antagonistic relationship that materializes in the series. The promotional materials promise portrayals of alienated black youths, authentic locations, contemporary street apparel and urban settings. Further, the copy teases audiences with 'An incredible 4 nights of drama' suggesting not simply a new drama on the Channel, but a media event. Such an array of signifying practices combines to produce a strong idea of Top Boy's visual, aural and narrative authenticity. In addition, Youth ad agency Livity effectively maximized the use of social media as a form of promotion and engagement targeted at what Channel 4 identified as 'hard to reach audiences'. Top Boy achieved over one million OnDemand views online and 123,000 tweets during the week of its broadcasting, becoming the most tweeted Channel 4 programme since the Channel began analyzing social media interaction. Further, there were over 23,000 plays of the drama's soundtrack. At its impact level, as well as its 1.1 million viewership, positive reviews and requests by schools across London for educational film screenings, the series also achieved critical acclaim, winning a Broadcast Award for Best Drama Series.

These frames of production and interpretation are important in how we understand the linkages between crime, media and culture. Considering the effect of ideological 'codes' on televisual communication, Hall states 'they refer signs to the 'maps of meaning' into which any culture is classified; and those 'maps of social reality' have the whole range of social 
meanings, practices and usages, power and interest 'written in' to them' (Hall, 1980: 57). How do these codes produce meanings of the social groups represented in Top Boy? How is 'crime' understood in these community contexts and what does this tell us about changing discourses of multiculturalism? The drama itself centers on 26-year-old drug dealer and gang leader Dushane (Ashley Walters) and his aims to rise to the apex of the East London drugs business, assisted by his friend Sully (Kane Robinson). The linear, cause-and-effect narrative takes the spectator through a number of dramatic set pieces - primarily, the violent acts of Dushane and Sully in their efforts to monopolise East London's drugs trade. The emotional heart of the drama lies with Ra'Nell (Malcolm Kamulete), a thirteen-year-old fending for himself in the absence of his mentally ill mother Lisa (Sharon Duncan Brewster). Ra'Nell's best friend Gem (Giacomo Mancini) is enticed into Dushane's drugs cartel whilst pregnant Heather (Kierston Wareing) coheres Ra'Nell into her cannabis-growing scheme to raise the deposit that will help her to move off the estate. Tellingly, in a panel of local youths assembled by the Observer newspaper to critique the show, Heather emerged as 'the most virulently disliked by our panel. Not because she is white, maybe because she is middle-class, but definitely because she wants to get out' (Observer, 2011). As the relationship between her and Ra'Nell develops, we get the sense that Heather possesses a very basic desire, a dream of a middle class home life that contrasts from the urban 'ghetto' environment that so appals her. By setting up this basic aspirational contrast, the drama achieves a binary sympathy for the young of the Hackney and hostility towards Dushane and Sully, who desire only profit and dominance over others, and at any cost.

These storylines are condensed in interwoven narrative structures that attempt to demonstrate how the drugs trade (in a localized context) impacts the lives of the residents on 
the fictional Summerhouse Estate. This is also why Top Boy is an ensemble drama, with many of its characters of equal narrative significance. Visually, the directors Yann Demange (series one) and Jonathan Van Tulleken (series two) attempt a social realist treatment of the milieu of disenfranchised black British youths. Both directors display a keen eye for detail and careful composition and there is a definite realist approach to the way they frame Hackney; sequence shooting and deep focus cinematography, with a fidelity to real-time. The natural lighting and the hand-held, cinema verite camera action employed to generate spontaneity are all used to marry cast and location together and give the impression that the fictional situations emerge spontaneously from the real social context.

The opening images of Top boy's first episode consist of establishing shots of East London tower blocks, hand-held images of black youths loitering against a car, our protagonists supervising a drugs deal while members of their crew are robbed at gunpoint by a rival all-black drugs gang to the soundtrack of urban music. This is observed from afar by an isolated and impressionable Ra'Nell. This sequence, which all takes place within three minutes, offers an indication of the representational strategy central to Top Boy. The geographical specificity of the show (a young boy is sent by Dushane to spy on a gang in London Fields) invites a literal representation of Hackney modelled on working class housing estates. Top Boy frames crime as a means of social mobility and greed is central to the text, as indicated in the series' title. In this way, Top Boy is about capitalism, the violent accumulation of wealth and its tragic consequences. Tellingly, one of the duo's first acts after being given control of Summerhouse by drugs lord Bobby (Geoff Bell) is to sever the fingers of a rival criminal with a wire cutter, followed by a collection of violent reprisal attacks on various members of Hackney's underworld. In two successive acts, Dushane and Sully set alight a 
relative of a rival and shoot dead Bobby's right hand man Lee (Cirus Desir). Here, Dushane and Sully are crafted as anti-heroes, modern gangsters and the drama has begun its critical turn away from social analysis into a culturally verisimilitudinous urban spectacle.

As an unsurprising consequence, there is little interaction between Bennett's characters and the wider social authority (school, educators) and a striking limit to the social realist ideals in Top Boy is the assumed exclusion of state institutions. In Top Boy's second series, broadcast over four one-hour shows in November 2013, there is a concerted attempt by Bennett to expand both the thematic concerns and the nuances of Hackney's criminal world. The most obvious change is in the appearance of state authority; the police feature more prominently as an antagonistic feature and several instances of stop-and-search appear to suggest that the writer is tapping into high profile issues in the public domain, with a greater willingness to display a more realistic relationship with characters and the state apparatus. However, this set-pieced presentation in Top Boy does not convincingly offer a critique of institutional racism towards young black males. Rather, there are small asides such as the passing comment by Dusane, in which he casually states that his detainment by police on a murder enquiry was "a harassment ting”. In such casually delivered dialogue, Top Boy embodies its evasiveness to actual social criticism. This casual narrative injection entails no real attempt to analyze the 'real' relationship between black youths and the Criminal Justice System; it does not engage critically with realistic conflicts between the Metropolitan Police and the BAME community.

The increase in non-black characters offers a visual sense of an integrated Hackney. Whilst this may be an attempt to interrupt hegemonic televisual representations of urban crime as a black idiolect, one of the virtues of the show is that the characters are not easily 
homogenised. Further, while stereotypical instances of single-parent families are frequent in series one, fatherhood becomes a continuing narrative thread in this second outing. The paternal instincts of both Dris (Shone Romulus) and Sully show to their children (and in the case of Sully and Jason, the young he can identify with his through his own turbulent childhood) is an attempt to create more three-dimensional characters and demonstrate that the relationship between the elders and youngsters on the estate is not solely determined by their practical use as drugs runners. Stuart Hall problematizes what can be identified as the "positive/negative strategy" suggesting that even positive images amidst the "largely negative repertoire of the dominant regime of representation'...' does not necessarily displace the negative. Since the binaries remain in place, meaning continues to be framed by them' (Hall, 2001: 274). In other words, such narrative strategies do not recast being a young black male as a positive identity with the same dramatic focus. Rather, this reframing focuses on the entirely different identity of fatherhood. This utility can be identified in a simple minor subplot. In episode three of the second series Sully sits a famished Jason down over a pizza whilst inspecting the poor condition of the child's teeth. As he advises, "My mum, all she cared about was fucking junk. Doesn't exactly set you up for life does it, having a mum like that. You have to overcome all of that, trust me Jase... you have to make something of this life even amongst all of this shit!" In this exchange, Sully is both educating Jason and berating broken Britain.

Lisa McKenzie (2015) has taken up the absence of context within media representations of Britain's working classes, arguing that such strategies chime with the discourse of 'the underclass and their lack of common societal values and morality, and their wilful self destruction and self destructive behaviour' (100). Top Boy's socio-political message, which is 
executed via the sentimental emphasis on Jason's emotional and physical suffering, is supported by a sense that none of the problems depicted in the series; economic inequality, crime, drugs, the youth, poverty and hunger, are socio-political consequences. This subplot demonstrates how Bennett has subtracted the socio-political influence on human decision amongst his newly created white working class characters; Jason's family's obvious problems are disconnected from the very social policy Bennett is proposing to critique. Thus, as in the first series, Top Boy is not ballast in any tangible socio-political realism but requires that the audience adopt a moral position based on the understanding of the character's behaviours and motivation. As result, we uncover through a series of clichés, a narrative conflict between the cinematic realism of Van Tulleken's visualized Hackney and inauthenticity of Bennett's dramaturgy. Thus, the problems are self-inflicted; this is the sole conclusion that can be surmised when the environment's relationship with the broader social context is extracted. At the very least, Top Boy offers no socio-political position in which to view either Dushane or his young disciples, and instead performs as a moral critique of an immoral social landscape.

The political liberalism of the broadsheet press provides a telling framework for understanding these representations. For the Guardian, Series One was praised for 'giving daring and ground-breaking work a platform to shed light on pressing issues from an informed perspective' (McVeigh, 2011). The reluctance of cultural commentators to thoroughly interrogate representations of BAME representations remains a key issue in cultural commentary, in which aesthetic and critical judgement typically become muddled (Ross, 1996). In sum, Top Boy is constructed by these hegemonic approaches to race and class representation. Such approaches, as we have argued in this article, show an inability to relate any social commentary imperative into an effective narrative strategy. This, in turn, produces 
a text that is unable to provide a form of representation that distinguishes between, on the one hand, urban crime as a matter of individual failings, and on the other, as a socio-political consequence beyond human control.

Of course, Top Boy does and should show that oppressed groups possess moral failings like anyone else but this does not override the stereotypical premise of black identities on which it operates. For Top Boy, the representational schemas do not reside outside mainstream discourse but can be seen as being embedded in the very discourses they claim to challenge. Therefore, the identity conferred by such representational strategies colludes with dominant trends of media representations that affirm liberal, middle class anxieties that produce both fascination and fear. The critical responses to the series demonstrates how this form of decontextualized representation can easily be appropriated by reactionary discourses that subsequently serve to feed imaginations; in this case, Hackney as a remote but dangerous place where 'black' and 'crime' appear as almost synonymous concepts. Further, the very concept of PSB has changed vis-à-vis shifting concepts of multiculturalism (on Channel 4) and the remit that marries both.

This industrial context is therefore critical to the analysis of Top Boy and reaffirms that such dramas are never organic but are determined by a range of interwoven political, economic, industrial and cultural forces at the time of their production. Public service broadcasters, it is suggested, have assumed that culturally verisimilar elements (rather than social realist ones) guarantee audience appeal and expectancy. Therefore, the commercialization of Channel 4 and a broader post-multicultural agenda has performed a gradual but no less decisive role in disarticulating the socio-political narratives that have arisen within the recent context of PSB. In other words, post-multiculturalism has also 
combined with neoliberalism at an economic level - shifting away from economic discourses of inequality and social division to cultural based discourses around inclusion. This in turn has resulted in the dwindling of more authentic televisual practices on Channel 4 and instead provided a visual hotline to the social anxieties and grievances of the present day.

\section{Conclusion}

The major concern of this article has therefore been to consider, through an analysis of Top Boy, the rise and allure of the black urban crime narrative, best understood against the vexed backdrops of (post) multiculturalism and PSB. The critical responses to Top Boy highlight the complicit, cultural relationship between different aspects of the media in constructing ideas of criminality through understandings of racial difference. The article has explored how such narratives come to be internalized and reified by creative producers and public service broadcasters in order to uphold the liberal and 'realistic' credentials of the black urban crime drama on television and, in turn, reframe wider public understandings of black masculinity. Various, overlapping circumstances have helped produce a genre that is strongly dependent on notions of authenticity and realism, but which actually lacks a rigorous positioning of the lived contexts in which criminal activity has taken place. Top Boy exemplifies a postmulticulturalist shift away from addressing issues of inequality and towards a suitablypackaged commodification of urban culture couched in the language of diversity and authenticity and articulated through the tools of social realism. The conception, production and reception of Top Boy all converge around these different cultural, industrial and commercial currents. 
We conclude by outlining how Top Boy highlights three critical imperatives in relation to the black urban crime genre. Firstly, the genre is both temporal and cyclical; its presence is aligned with broader media narratives and a complex combination of cultural, political and industrial conventions. Secondly, the genre cannot be seen simply as the product of any single author's vision, but as brought into being through a number of cultural dynamics. Thirdly, the black urban crime dramas should not be conflated with socio-political dramas. Whilst we have been arguing that the dramatization of media discourse of black criminality and its hybrid verisimilitude produces an allure for the spectator, it might also be contended that Top Boy's critical success is the result of the drama's rejection of a definite political position (and thus a perfectly post-multiculturalist cultural product). As discussed by Wilson (2014) in his discussion of HBO's The Wire, 'realism, if uncritical, can become poverty porn at best, another means of controlling the underclass at worst; in both cases realism's revolutionary potential will be safely contained by the system' (71).

For all its generic verisimilitude, the absence of socio-economic realities produces a text easily consumable for an audience's fascination with the 'other'. The crossover imperative that has characterized the genre compromises any socio-political imperatives that the practitioner may wish to communicate, therefore challenging our understandings of social realism. Instead, they emerge through modes of realism that reduce its characters to peculiar objects for the benefit of middle class, liberal observation. To this end, Top Boy is archetypal of UK urban drama in every way that we now conceive of the genre, indicative of a further incremental step away from black as a political term to, paradoxically, a commoditized product within the framework of a post-multicultural PSB imperative (Malik, 2013). This article poses empirical questions not only of what constitutes an urban drama, but whether 
post-multicultural television drama, however defined, can articulate counter-hegemonic perspectives and present an authentic image of our socio-political realities, including those that relate to crime and black Britain.

\section{References}

Bennett, R (2011), 'Top Boy: Stories of Hackney's young drug dealers', The Observer 09 October.

Best, J (1995), Images of Issues: Typifying Contemporary Social Problems, New York: Aldine de Gruyter.

Bignell, J., Lacey, S. and Macmurraugh-Kavanagh, M. (Eds.) (2000), British Television Drama: Past Present and Future, Basingstoke: Palgrave Macmillan.

Broadcasting Act (1981) Available at: www.legislation.gov.uk (accessed 7 June 2014)

Brown, M (2007), A License To Be Different; The Story of Channel Four, London: British Film Institute.

Channel 4 (2013) Top Boy, Available at: www.channel4.com (accessed 6 June 2014)

Christie, N. (2001) 'Det idealiska offret [The Ideal Victim]. in M. Akerstrom and I. Sahlin. Det motspanstiga offret [The Defiant Victim]', pp. 46-60. Lund: Studentlitteratur.

Duyne, VP (2003), 'Organising cigarette smuggling and policy making. Ending up in smoke’, Crime, Law and Social Change, 39: 3, pp. 285-317.

Ellis J (1981), Visible Fictions: Cinema, Television, Video. London: Routledge

Ellis, J (1999), 'Television as Working Though', in Griprud J (ed.) Televsion and Common Knowledge. London: Routledge.

Fiske, J (1987), Television Culture, London, Methuen. 
Friedman, L (1993), Fires Were Started: British Cinema and Thatcherism, London: Routledge.

French, P (2005), 'When young guns go for it', The Guardian, 10 April.

Gilroy, P (1987), There Ain't No Black in the Union Jack, London: Hutchinson.

Hall, S, Critcher C, Jefferson T, Clarke, J and Roberts, B (1978), Policing the Crisis: Mugging, the State and Law and Order, London: Macmillan.

Hall, S (1980), 'Encoding/Decoding', in Hall S, Hobson D, Love L and Willis P (eds.) Culture, Media, Language, London: Hutchinson.

Hall, S (1995), Negotiating Caribbean Identities. New Left Review 209, pp. 3-12.

Hall, S (2001), 'The spectacle of the other,' in Hall, S. (ed.) Representation: Cultural Representations and Signifying Practices, Milton Keynes: Open University Press

Hallsworth S and Young T (2008) 'Gang talk and gang talkers: A critique'. Crime Media Culture 4:2, pp. 175-195.

Hobbs, D (2006), 'The Nature and Representation of Organised Crime in the United Kingdom', in Fijnaut C and Paoli L (eds.) Organised Crime in Europe: Concepts, Patterns and Control Policies in the European Union and Beyond, New York: Springer

Hobson, D (2007), Channel 4: The Early Years and the Jeremy Isaacs Legacy, London: IB Tauris \& Co.

Iqbal, N (2013), 'Ashley Walters and Kano: Top Boy hit the nail on the head', The Guardian, 9 August.

Jauss, HR (1982), Towards an Aesthetic of Literary Reception, Brighton: Harvester Press. Jewkes, Y (2004), Media and Crime, London: Sage.

Lukacs, G (1978), 'Narrate or Describe', in Writer and Critic, Pontypool: The Merlin Press 
Malik, S (2013), 'Creative Diversity: UK Public Service Broadcasting After Multiculturalism', Popular Communication: The International Journal of Media and Culture, 11: 3, pp. 227-241.

McKenzie, L (2015), 'Getting By: Estates, Class and Culture in Austerity Britain', Bristol: Policy Press.

McVeigh, T (2011), 'Top Boy gets a mixed reception from Hackney's youth', Observer 30 October.

Mercer, K (1987), Black Film, British Cinema, London: ICA Documents.

Mercer, K (1994), Welcome to the Jungle: New Positions in Black Cultural Studies, London:

Routledge.

Metcalf, J (2012), "Reviewing "monsters": the press reception and media constructions of contemporary street gang memoirs', Crime Media Culture 8: 3, pp, 333-353.

Nwonka, CJ (2015), 'Diversity pie: Rethinking social exclusion and diversity policy in the British film industry', Journal of Media Practice 16: 1, pp. 73-9.

Neale, S (2000), 'Questions of Genre, in Stam R and Miller T (eds.) Film and Theory: An Anthology, New York: Blackwell Publishing.

Ross, J (2011), 'Britney Spears shoots criminal video as council bars gang drama filming on Hackney estates', Hackney Citizen, 23 September.

Ross, K (1996), Black and White Media: Black Images in Popular Film and Television, Cambridge: Cambridge University Press.

Rowe, M (2012), Race and Crime: Key Approaches to Criminology, California: Sage Publications.

Solomos, J (1988), Black Youth, Racism and the State: the Politics of Ideology and Policy, 
Cambridge: Cambridge University Press.

Stelfox, P (1996), 'Gang Violence. Strategic and Tactical Options', London: Home Office Police Research Group

Thompson, T (2003). 'Without a gun, you're dead', The Observer 21 September.

Todorov, T (1981), Introduction to Poetics, Minneapolis: University of Minnesota Press.

Vertovec S (2010) 'Towards post-multiculturalism? Changing communities, conditions and contexts of diversity', International Social Science Journal, 61: 199, pp. 83-95.

Vinen, R (2010), 'Thatcher's Britain: The Politics and Social Upheaval of the 1980', London:

Simon \& Schuster.

Wayne, M (2002), Politics in Contemporary European Cinema: Histories, Borders, Diasporas', Chicago University of Chicago Press

Welch, K (2007), 'Black criminal stereotypes and racial profiling', Journal of Contemporary Criminal Justice 23: 3, pp. 276-288.

Williams, R (1977), ‘A lecture on realism', Screen, 18: 1, pp. 61-74.

Wilson, G (2014), 'The bigger the lie, the more they believe. Cinematic realism and the anxiety of representation in David Simons' The Wire', Texas, A\&M University South Central Review, 31: 2, pp. 59-79.

Wintour, P (2007), 'Blair blames spate of murders on black culture', The Guardian, 12 April. 